Удк 351:316

Г. П. Ситник,

Ә. держ. упр., професор, професоркафедри державного управління філософського

факультету, Київський начіональний університет імені Тараса Шевченка

ORCID ID: 0000-0002-3083-5733

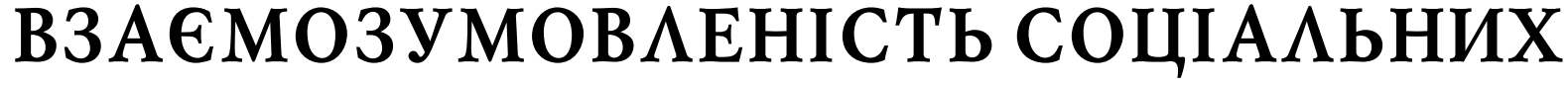 ЯВИЩ, ЯКІ ВИЗНАЧАЮТЬ КОНЦЕПТАМИ "НЕБЕЗПЕКА" I "БЕЗПЕКА", ТА ЇÏ ВРАХУВАННЯ В ТЕОРІЇ ПУБАІЧНОГО УПРАВ $\Lambda$ IHНЯ
}

G. Sytnyk,

Doctor of Sciences in Public Administration, Full Professor,

Professor at the Department of Public Administration, Taras Shevchenko National University of Kyiv

THE INTERCONDITIONALITY OF THE SOCIAL PHENOMENA THAT DETERMINE

THE CONCEPTS OF "DANGER" AND "SECURITY", AND ITS CONSIDERATION

IN THE THEORY OF PUBLIC ADMINISTRATION

Встановлено, що соціальне явище за об'єктивним змістом є небезпекою для соціальної системи, якщо є заперечення її існуванню. Воно є властивістю її буття, тому у науковому сенсі доцільно говорити не про поняття, а про концепт "небезпека", бо заперечення міститься в системі, що зумовлено єдністю сталості й змінності, спрямованістю і формами їі розвиткузгідно з законом "заперечення заперечення". Показано, що небезпеки є формою оцінки заперечення буття системи й мають спонукати її до відповідних рішень, розрізняючи об'єктивні фактори, як заперечення її існування і суб'єктну форму їх відображення, що зумовлює важливість якіснокількісних характеристик причин й динаміки небезпек. Доведено, що явище, яке визначають концептом "безпека" існує лише в живій природі, є соціокультурним феноменом, а його сутність має розкриватися через сутність концепту "небезпека", та що він є науковою категорією, яка відображає універсальні властивості та закономірності розвитку матеріальних, природних $i$ духовних явищ елементів реального світу. Встановлена доцільність дослідження онтологічного, гносеологічного та аксіологічного аспектів проблеми забезпечення безпеки та встановлено, що безпека людини - це стан і категорія, які характеризують її самопочуття і впевненість, що небезпеки, наприклад, її життю чи майну, відсутні, або для їх захистує відповідні засоби; безпека суспільства і державних інститутів - стан і категорія, які характеризують свободу вибору шляхів їх прогресивного розвитку, яка грунтується на державному суверенітеті, або вони належним чином захищені. Обгрунтовується важливість визначення якісно-кількісних характеристик переходу соціальних систем в інший стан, визначених на основі результатів філософсько-політологічного, правового, ціннісного, етичного аспектів проблеми забезпечення ії безпеки та врахування законів еволюції живої речовини в біосфері.

It is established that a social phenomenon in objective content is a danger to the social system, if there are objections to its existence. That it is a property of its being, therefore, in the scientific sense it is advisable to talk not about the concept, but about the concept of "danger", because the 
negation is contained in the system, which is due to the unity of stability and variability, direction and forms of its development according to the law of negation of negation. It is shown that hazards are a form of assessment of the negation of the existence of a system and should encourage it to appropriate decisions, distinguishing between objective factors, such as the denial of its existence and the subjective form of their reflection, which determines the importance of qualitativelyquantitative characteristics of the causes and dynamics of hazards. It is proved that the phenomenon that is defined by the concept of "security" exists only in living nature, is a sociocultural phenomenon, and its essence must be revealed through the essence of the concept of "danger", and that it is a scientific category, reflects the universal properties and patterns of development of material, natural and spiritual phenomena of the elements of the real world. The expediency of studying the ontological, epistemological and axiological aspects of the problem of ensuring safety has been established, and it has been established that human security is a condition and category that characterize his well-being and confidence that there are no dangers, for example, his life or property, or there are appropriate means to protect them; the safety of society and state institutions - the state and category that characterize the freedom to choose the paths for their progressive development based on state sovereignty, or they are duly protected. It substantiates the importance of determining the qualitative and quantitative characteristics of the transition of social systems to another state, determined on the basis of the results of philosophical and political science, legal, value, moral aspects of the problem of ensuring its safety and taking into account the laws of evolution of living matter in the biosphere.

Ключові слова: небезпека, безпека, концепт, публічне упраВління, соціальне яВище, соціальна система, категорії: якість, кількість, структура, форма, зміст.

Key words: danger, security, concept, public administration, social phenomenon, social system, categories: quality, quantity, structure, form, content.

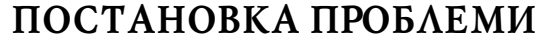

\section{У ЗАГА}

Розкриття сутності соціальних явищ, які традиційно позначають поняттями "небезпека" та "безпека" має важливе значення в теорії національної безпеки та теорії публічного управління. Це зумовлено тим, що зміст цих поняття тією чи іншою мірою відображає універсальні властивості та загальні закономірності розвитку матеріальних, природних й духовних явищ (систем, об'єктів, процесів тощо) реального світу. На це звернули увагу ще в стародавні часи розглядаючи забезпечення безпеки, як одного з критеріїв ефективного державного управління. Не менш важливим $є$ й з'ясування взаємозв'язку та взаємозумовленості цих понять та їх місця у інтерпретації й операціоналізації інших понять, зокрема, таких як "небезпека людині", "національна безпека", "державна безпека". Тому дослідженню соціальних явищ, які є причинами небезпек буттю соціальних систем, а також теоретичних основ формування механізмів забезпечення їх безпеки науковці традиційно приділяють значну увагу. Ці питання перебувають й у колі інтересів політиків та управлінців. Проте це не є переконливим доказом розкриття сутності взаємозумовленост соціальних явищ, які вони традиційно визначають поняттями "небезпека" та "безпека", пропонуючи різні трактування їх змісту. Це породжує значні труднощі у інтерпретації та операціоналізації цих понять у теорії публічного управління та зумовлює актуальність подальших досліджень взаємозумовленості соціальних явищ, які традиційно визначають поняттями "небезпека" та "безпека".

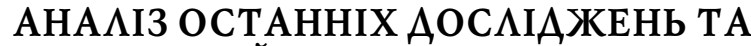 ПУБАІКАЦІЙ}

Як відомо, велика сукупність понять не обов'язково зумовлює якісний перехід від суб'єктивних уявлень до розуміння сутності явища, як елементу реального світу. Це стосується й явищ, які $є$ фрундаментальною характеристикою буття соціальних систем та які традиційно визначають поняттями "небезпека" та "безпека". Ще в античні часи фрілософи, звернули увагу на те, що забезпечення безпеки громадян $є$ одним із засобів досягнення загального благополуччя [1]. Проте фрактично до XVII ст. ця проблема не перебувала у колі наукового та публічного дискурсу. Процеси формування абсолютних монархій в Європі активізували пошук шляхів раціонального формування систем державного управління Це зумовило й увагу щодо аналізу факторів, які на той час визначались як небезпеки для них, зокрема, з боку, Т. Гоббса, Дж. Локка, Гегеля, Ж.-Ж Руссо, які намага- 
лися обгрунтувати шляхи забезпечення безпеки людини (індивіда), суспільства, державних інститутів [2-5]. Прискорення процесів глобалізації спонукало Е. Дюркгейма, Ж. Бодрійяра, З. Баумана, М. Фуко та інших до досліджень проблеми забезпечення безпеки людини (індивіда) та суспільства, результати яких дозволяють здійснювати пошук адекватних управлінських рішень у сфрері національної безпеки [6-9]. Але й до цього часу поняття "небезпека" та "безпека" не розглядаються як наукові категорії, незважаючи на те, що вони відображають універсальні властивості та закономірності розвитку матеріальних, природних й духовних явищ, як елементів реального світу. Це не дозволяє розглядати ці поняття як когнітивні одиниці, що забезпечують перенесення знань у міждисциплінарних дослідженнях, якими $€$ дослідження проблем забезпечення безпеки, або здійснити перехід від теорії національної безпеки до теорії публічного управління. Викладене зумовлює подальші дослідження об'єктивно-суб'єктивної природи взаємозумовленості соціальних явищ, які традиційно визначають поняттями "небезпека" та "безпека".

\section{META CTATTI}

Метою статті $€$ розкриття сутності взаємозумовленості соціальних явищ, які визначають концептами "небезпека" та "безпека".

\section{ВИК ААА ОСНОВНОГО МАТЕРІААУ}

Загальновідомо, що у процесі еволюційного розвитку сформувався інстинкт самозбереження живих істот, суть якого полягає у спроможності виявляти та оцінювати фактори, що можуть бути причинами небезпек їх існуванню. Тому для буття будь-якої соціальної системи визначальними є фактори, які заперечують її існування, а відтак спонукають ії̈ до активних захисних дій. Саме ці фрактори (соціальні явища) ідентифрікуються системою як "небезпеки". Небезпека як соціальне явище завжди має об'єктивно-суб'єктивний характер, а ступінь співвідношення суб'єктивності та об'єктивності може бути різним, адже одна й та сама дія може отримати 3 боку суб'єкта різну оцінку у контексті можливих негативних наслідків для його буття. Тому оцінка цих наслідків фрормує у суб'єкта ставлення до того чи іншого соціального явища як небезпеки. Крім того, людина може оцінювати небезпеку опосередковано, тобто переносити свою оцінку на інші об'єкти й суб'єкти. Водночас цьому одне й те ж соціальне явище може оцінюватися нею чи як небезпечне, чи як безпечне, залежно від її ціннісних орієнтацій.

Таким чином, соціальне явище за об'єктивним змістом $€$ небезпекою для соціальної системи, якщо має місце заперечення природної визначеності її буття. Можливість заперечення міститься у самому предметі, тобто, якщо є предмет, то $є$ й можливість заперечення його існування, що зумовлено єдністю сталості й змінності, спрямованістю й формами розвитку будьякого предмету закону "заперечення заперечення". Це означає, що фракт існування предмету приховує у собі можливість заперечення його буття, тому що за своїм змістом можливість небезпеки існує не ззовні, а всередині предмету, якому небезпека загрожує як заперечення важливих для його буття характеристик, тобто тих, що визначають його цілісність та індивідуальність. Загалом можна дійти таких висновків: соціальне явище, яке соціальна система визначає концептом "небезпека" $\epsilon$ формою його оцінки як заперечення ії̈ буття системи, але варто розрізняти об'єктивні фактори існування явища та суб'єктну форму його відображення; ототожнення об'єктивного змісту соціального явища як небезпеки для системи з суб'єктною формою його сприйняття призводить до перенесення суб'єктивного змісту на це явища, яке може й не відповідати його сутності; небезпекою для соціальної системи є об'єктивна можливість негативної дії на неї соціальних явищ унаслідок чого суттєво погіршиться ії̈ стан, або виникне небажана динаміка її розвитку. Водночас зміст і форми прояву небезпек можуть бути різними, зокрема, можна говорити про небезпеки в економічній чи політичній сорерах, а щодо суб'єктів та механізмів їх реалізації - про зовнішні та внутрішні небезпеки. Зовнішня небезпека для соціальної системи - це об'єктивна можливість негативної дії соціальних явищ, що перебувають поза її межами, а внутрішня - можливість елементів структури системи, за певних умов завдати шкоди системі.

Свідомість людини дає їй змогу відображати та оцінювати заперечливий вплив небезпеки щодо її буття, соціальної групи тощо й на цій основі визначати своє ставлення до нього. Тому соціальне явище, яке традиційно визначають поняттям "небезпека" $є$ соціокультурним феноменом, який має об'єктивно-суб'єктивну природу та $є$ невід'ємною властивістю буття й розвитку соціальних систем, оскільки воно: може бути пізнане на основі досвіду; має латентний характер; свідчить про сутнісні характеристики соціальних об'єктів; стосується відносин та подій між індивідами у суспільстві в цілому, а відтак у науковому сенсі доцільно говорити не про поняття, а про концепт "небезпека".

Викладене вище має принципове значення, наприклад, при інтерпретації та операціоналізації поняття "національна безпека". Дійсно, якщо небезпека опосередковується із запереченням буття суб'єкта, то безпека його існування опосередковується й визначається ним за ставленням до небезпеки. Водночас можуть бути такі досить очевидні ситуації: відсутність небезпеки для суб'єкта, як наслідок його захищеності від неї; наявність небезпеки та захищеності суб'єкта; відсутність небезпеки та захищеності суб'єкта. Тому безпека суб'єкта не тотожна відсутності небезпеки для нього, але водночас вона не існує без соціального явища, яке суб'єкт ідентифрікує як небезпеку. Іншими словами, як і небезпека, безпека будь-якого об'єкта для людської спільноти завжди є суб'єктним визначенням, а відтак завжди існує небезпека неадекватної оцінки безпеки об'єкта, коли суб'єкт її оцінювання починає діяти виходячи з власних уявлень про небезпеку, а не реальної небезпеки, а відтак має місце проблема визначення межі між наявною й суб'єктивно визначеною як небезпекою, так і безпекою. Разом з тим, очевидно, що безпечними впливами на об'єкт можуть вважатися ті, що не призводять до істотної зміни його буття, зміни структури тощо. Тому ми погоджуємося з науковцями, зокрема, В. Могилевським, які пропонують розглядати безпеку як специфрічну властивість динамічних систем та як комплексний кри- 
терій оцінки її якості, який характеризує динаміку її розвитку [10, с. 225].

3 огляду на викладене, концепт "безпека" має розглядатися як наукова категорія, яка відображає універсальні властивості та загальні закономірності розвитку матеріальних, природних і духовних явищ. 3 одного боку, категорії $€$ найзагальніші поняття, які не піддаються визначенню в рамках однієї теорії та $є$ елементами категоріальних схем процедур мислення, а з іншого вони, як фрілософські поняття, використовуються під час систематизації знання, як когнітивні одиниці, що забезпечують процеси перенесення знань в міждисциплінарних дослідженнях, фіксують етапи пізнавального процесу й дозволяють здійснити перехід від однієї до іншої галузі знань [11]. На цю особливість соціального явища, яке визначають концептом "безпека", звернули увагу ще античні мислителі, які у своїх фрілософських і політико-правових вченнях, досліджуючи проблеми підвищення ефективності управління державою, розглядали забезпечення безпеки громадян як один з засобів досягнення загального благополуччя [1]. Проте особливу увагу цій проблемі почали приділяти починаючи з XVII ст., зокрема, Т. Гоббс, Дж. Локк, Г. Гегель, Ж.-Ж. Руссо, А. Сен-Сімон [2-5; 8].

Так, Т. Гоббс дійшов висновку, що страх перед небезпеками змушує людину жити у суспільстві й шукати в ньому засоби колективного захисту від них, а відтак, на його думку, люди, піклуючись про власну безпеку, делегують свою свободу абсолютній владі суверену, оскільки у разі вибору свободи безмежного самоствердження можуть залишитися у природному стані дикості, за якого ніхто не зможе їм гарантувати особисту недоторканність й безпеку [2]. Він був переконаний, що заради життя й безпеки можна поступитися добробутом, а суверен має надавати захист від ворогів й зберігати мир усередині суспільства. Уявлення Дж. Локка про безпеку людини грунтувалися на тому, що коли держава перестає гарантувати безпеку, або сама стає джерелом небезпеки для громадян, вони мають право забезпечити свій захист від таких дій держави й, таким чином, гарантувати найважливіші права, а саме: народ має право відібрати владу у тих, хто буде нехтувати його інтересами та вручити ії іншим, більш гідним довіри. Проте виникає парадоксальна ситуація - народ, який одержує право скасовувати владу, може здійснити це право, але це повертає суспільство до стану, який характеризується відсутністю безпеки [3]. Значну увагу осмислення уявлень про безпеку приділив Г. Гегель, який надавав пріоритет забезпеченню безпеки держави, яка, на його думку: має особливий характер цілісності; фрункція забезпечення безпеки є вищою договірної природи держави; може вимагати від індивідів, щоб їх життя й власність, за необхідності, були принесені в жертву загальним інтересам, оскільки вони забезпечуються лише безпекою держави, тому найнебезпечнішими є злочини проти держави [4]. На думку Ж.-Ж. Руссо, громадяни мають залишатися абсолютно вільними й не обмеженими діями держави, оскільки саме народ $є$ носієм й джерелом влади [5], а А.Сен-Сімон намагався розв'язати проблему забезпечення безпеки громадян у контексті ліквідації будь-якої соціальної ієрархії, тобто запровадження тотальної рівності усіх, длячого вважало- ся за необхідне ліквідувати такі інститути, як приватна власність, держава, сім'я [12].

Значний внесок у сучасне розуміння безпеки зробили Е. Дюркгейм та Ж. Бодрійяр. Так, Е. Дюркгейм, вважав, що визначальними елементами забезпечення безпеки індивіда мають бути соціальні норми, спрямовані на обмеження їх егоїстичних прагнень, запобігання різним соціальним конорліктам та їх врегулювання [6], а Ж. Бодрійяр вважав, що сьогодні влада здійснює виробництво безпеки (від воєнної безпеки й закінчуючи страхуванням від нещасного випадку) і, таким чином, ми завжди маємо справу з конвертацію смерті (нещасного випадку, тощо) в капіталістичний надприбуток [7]. Як М. Фуко, до кола наукових інтересів якого належали з'ясування генеалогії влади [9], він убачає у такій еволюції змісту концепту "безпека" розвиток логічних передумов теорії "суспільного договору", де влада наділяється правом змусити померти й дозволити жити, а через симетрію з'являється й нове її право: право змусити жити й дозволити померти, відтак пояснює це метою влади, яка прагне контролювати життя як таке. Варто зазначити, що такі погляди на природу влади у Ж. Бодрійяра, М. Фуко, а також певною мірою у З. Баумана [8], зумовлюють й відповідні уявлення про безпеку у представників фрілософії постмодерна, згідно яких, має місце тенденція, коли діяльність державних інститутів щодо захисту громадян від різних ризиків, нещасних випадків, тощо максимально розширює сферу гарантій їх безпеки, але, водночас, створюються й системи тотального контролю за діями людини, зважаючи на що, за певних умов, правові, інфрормаційні та інші заходи державної влади щодо забезпечення безпеки громадян, можуть насправді стати небезпекою для них. 3 цим важко не погодитися, тому, що сучасні трансорормації у різних сфрерах суспільного життя спонукають до подальшого з'ясування сутності соціального явища, яке визначають концептом "безпека", зокрема, онтологічного, гносеологічного та аксіологічного аспектів проблемиії забезпечення.

Онтологічний аспект полягає у тому, що безпека відображається у різних фрормах, як об'єктивні умови буття природи, людини, соціального й духовного, але, виходячи з викладеного вище, той чи інший предмет (об'єкт, процес, тощо), який визначається людиною як безпечний, за своєю природою може бути насправді небезпекою для неї, тому в об'єктивному сенсі забезпечення іїі безпеки може мати небезпечний характер. Це означає, що в контексті вивчення умов буття людини (індивіду), суспільства чи державних інститутів необхідно розрізняти їх безпеку, так би мовити, в природній визначеності від безпеки в суб'єктній визначеності. Люди, об'єднуючись у ті чи інші групи, встановлюють нормативно регульовані взаємовідносини, значною мірою керуючись прагненням забезпечити власну безпеки. Подвійна природа соціального явища, яке визначають концептом "безпека", в основі якої єдність об'єктивно існуючого інстинкту самозбереження живих істот й особливості форми прояву його в людській життєдіяльності, зумовлює важливість дослідження особливостей пізнання цього явища, тобто гносеологічний аспект проблеми забезпечення безпеки. Цей аспект дослідження пов'язаний з значними труднощами, оскіль- 
ки об'єктивно існує, з одного боку, безперервний процес об'єктивних змін зовнішнього й внутрішнього середовища соціальних систем, які породжують небезпеки їх буттю, а з іншого - практично відкрита множина оцінок причин і наслідків цих небезпек. Ці оцінки, як правило, включають явний чи латентний ціннісний контекст, оскільки як суспільне явище, безпека належить до загальнолюдських цінностей, таких як, наприклад, добро, справедливість та інші й має ціннісну значущість для багатьох поколінь людей (знання про передумови та механізми забезпечення власної безпеки дають людині свободу вибору), тому об'єктивно виникає необхідність дослідження і аксіологічного аспекту проблеми забезпечення безпеки

Таким чином, зміст і фрорма соціального явища, яке визначають концептом "безпека", пов'язується з наявністю умов буття соціальних систем, тому воно $є$ фундаментальною та системною характеристикою їх розвитку. Оскільки потреба в безпеці, виникла разом з появою людини на землі, то сутність цього явища акумулює в собі наслідки багатогранної діяльності цих систем: історичний досвід, культурні особливості, накопичені матеріальні цінності тощо. Тому можна стверджувати, що безпека людини - це водночас стан й категорія, які характеризують її самопочуття й впевненість (інтуїтивні чи такі, що базуються на знаннях), що небезпеки, наприклад, ії̈ життючи майну, відсутні, або для їх захисту $є$ відповідні засоби. Водночас безпеку суспільства та державних інститутів можна розглядати як стан й категорію, які характеризують передусім свободу вибору шляхів їх самовдосконалення та прогресивного розвитку, яка грунтується на державному суверенітеті, або ж вони належним чином захищені. Ілюзорна доступність трактування на інтуїтивно-побутовому рівні концепту "безпека", об'єктивно зумовлює широке його використання політиками, управлінцями та експертами, але наукові дискусії, зокрема, щодо вибору раціональної основи для структуризації та оцінювання небезпек безпеці (від людини до земної цивілізації) та вибору допустимих засобів й способів ії̈ забезпечення, свідчать, що у науковому сенсі вказане соціальне явище достатньою мірою не досліджене, не кажучи вже про те, що деякі тлумачні словники трактують поняття безпека як стан, коли немає небезпеки, або як стан, за якого ніщо декому або дечому не загрожує [13]. Й це при тому, що, як нами було показано вище, за будь-яких умов безпеку не можна розглядати як стан, коли немає небезпеки.

Очевидно, що у розкритті сутності соціального явища, яке визначають концептом "безпека", важливим $€$ з'ясування причин й динаміки його розвитку. Як ми зазначали, безпека, наприклад, людини (індивіду) - це водночас її стан і категорія, яка його характеризує, тому доцільним $є$ дослідження якісно-кількісного стану розвитку вказаного соціального явища, оскільки саме він відображає сукупність властивостей, ознак, у тому числі й його складових, тобто зміст та форму існування (буття) цього явища. Як відомо, зміст будь-якого предмету характеризує сукупність його об'єктивних властивостей, складових, ознак, а фрорма - сукупність зв'язків структури змісту. Зміст і фрорма предмету є співвідносними категоріями, (не буває неоформленого змісту або беззмістовної форми) й водночас можуть бути розкриті такими взаємопов'язаними категоріями буття як "якість" та "кількість", які є узагальненим відображенням буття, а також його структурою. Щодо соціального явища, яке визначають концептом "безпека", категорія "якість" характеризує внутрішню нероздільну визначеність та сукупність його суттєвих рис, й проявляється через його властивості, якими воно відрізняється від інших та яку не можна відділити від існування (буття) явища. Категорія "кількість", у свою чергу, є зовнішньою характеристикою явища у контексті ступеню розвитку його властивостей: величини, динаміки змін, кількісних наслідків, тощо, тобто тих, які можна виміряти. Структура ж явища як сукупність його елементів і зв'язків між ними відображає єдність, взаємозв'язок і залежність якості та кількості, які перебувають в нерозривній єдності згідно загальновідомого закону переходу кількісних змін в якісні, який розкриває найбільш загальний механізм розвитку явища у той чи інший момент його буття. Категорія "якість" дає нам змогу дійти висновку про сталість соціального явища, оскільки коли воно втратить свою якість, то перестає бути тим, чим було, а категорія "кількість" відобразити його мінливість. Таким чином, категорії "якість" та "кількість" характеризують соціальне явище з різних сторін, а їх взаємообумовленість проявляється в тому, що кількісна характеристика уточнює якісну характеристику, а будь-яка якість завжди має свої кількісні межі.

Як відомо, міра відмінності між старою й новою якістю об'єкту залежить від кількісних змін у ньому, тому його структура залежить від кількості елементів, які її утворюють, пов'язана з якістю і характеризує розподіл й взаємодію у просторі цих елементів у процесі буття об'єкта. Особлива властивість структури - цілісність та якісна відмінність від якісних характеристик елементів, тобто неможливість зведення властивостей об'єкта до суми властивостей його елементів. Тому розвиток соціального явища, яке визначають концептом "безпека", який зумовлює зміну його змісту та форми, завжди пов'язаний зі зміною структури явища, яка, в свою чергу, завжди пов'язана зі зміною якості та, навпаки, тобто твердження, що спочатку відбуваються кількісні зміни в явищі, а вже за ними якісні, $є$ невірним. Зміна якості завжди спричиняє зміну кількості, оскільки перехід одного явища в інше, $є$ наслідком процесу взаємодії кількісних й якісних змін, що проходять через проміжні фази зміни якості, які фріксують зміну міри даної якості, тобто по суті це кількісна зміна, а поява нової якості фрактично буде означати появу явища з новими закономірностями й мірою, в якій закладена вже інша кількісна визначеність. Значною мірою через об'єктивно-гносеологічну природу причин та динаміки соціального явища, яке визначають концептом "безпека", в останні десятиліття для вирішення комплексної проблеми її забезпечення почали залучати основні напрацювання отримані у теорії нелінійних процесів й теорії хаосу, а також синергетичну термінологію Це сприяє розумінню спонтанності й непередбачуваності небезпек як наслідків взаємодії процесів соціальної й природної самоорганізації соціальних систем. Зокрема, як зазначає М. Орел, синергетичний характер безпеки полягає у тому, що вона є наслідком взаємодії як цілісної системи інститутів політичної, економічної, соціальної та гу- 
манітарної сфрер життєдіяльності людини, суспільства, держави, а в деяких випадках і міжнародних інститутів [14].

Згідно з концепцією "суспільного договору" місією влади $є$ забезпечення безпеки людини (індивіда), суспільства та державних інститутів. Ефективність її досягнення значною мірою залежить від стану системи публічного управління, який зумовлює сукупність властивостей й ознак, тобто змісту та фрорми буття (існування) цієї системи. Так, функціями системи публічного управління $€$ планування, організація, контроль та ін. Саме вони визначають зміст діяльності її суб'єктів, а способи реалізації - фрорму їх діяльності (накази, нормативні акти, тощо). Розвиток соціальних систем зумовлює ті чи інші її стани, а відтак зміну їх змісту, а потім й форми, оскільки у разі їх невідповідності виникає конфрлікт, який має вирішуватися заміною фрорми на нову та зміною змісту. У кінцевому підсумку, суб'єкти системи публічного управління мають створювати умови, за яких гарантується певний рівень можливостей для задоволення потреб в безпеці людини, суспільства та державних інститутів. Він $є$ якісно-кількісною характеристикою явища, яке визнають концептом "безпека". Створення ж цих можливостей залежить від наявності у цих суб'єктів інструментів владного впливу на небезпеки та ефективності їх використання, яка залежить від низки фракторів. Оскільки безпекає суспільною потребою, то принципово важливим $€$ забезпечення суспільної злагоди щодо визначальних чинників забезпечення безпеки людини (індивіда), суспільства та державних інститутів, як передумови ефективності використання наявних інструментів владного впливу небезпеки. Тому для забезпечення реалізації наявних можливостей суб'єктів системи публічного щодо адекватного реагування на небезпеки та створення додаткових можливостей принципово важливим $€$ комплексне врахування фрілософрсько-політологічного, правового, ціннісного та етичного аспектів проблеми забезпечення безпеки.

Філософрсько-політологічний аналіз дозволяє розглянути процес забезпечення безпеки як суспільне явище, яке спрямоване на захист й підтримку державної влади й водночас пов'язане з інтересами життєдіяльності великих соціальних спільнот. Метою правого аналізу є з'ясуванням особливостей та меж правового регулювання взаємодії суб'єктів і об'єктів безпеки, які обумовлені національними та міжнародними правовими нормами (угодами, конвенціями тощо). Принципово важливими є й дослідження ціннісної та етичної сутності проблеми забезпечення безпеки, які дозволяють визначити етичні обмеження, що можуть здійснювати вплив на вибір засобів і способів ії̈ забезпечення, а відтак і характер взаємодії суб'єктів та об'єктів безпеки. Водночас має бути врахована й низка фракторів, які визначають сучасні тенденції розвитку земної цивілізації та національних спільнот. Йдеться передусім про необхідність врахування взаємозалежності тенденцій змін загальнолюдських, національних, групових та індивідуальних ціннісних орієнтацій в епоху постмодерну, а також законів еволюції живої речовини в біосфері, зокрема, закони незворотності та прискорення еволюційних процесів і біохімічні закони, які вивів В. Вернадський, що біогенна міграція хімічних елементів в біосфері прагне до максимального прояву й, що еволюція видів призведе до перетворення біосфери у ноосферу.

\section{ВИСНОВКИ}

1. Соціальне явище за об'єктивним змістом $є$ небезпекою для соціальної системи, якщо має місце заперечення природної визначеності її буття. Воно має об'єктивно-суб'єктивну природу, є невід'ємною властивістю їх буття, оскільки можливість заперечення вказаної визначеності міститься в ній, що зумовлено єдністю сталості й змінності, спрямованістю і формами розвитку згідно закону "заперечення заперечення", а ступінь суб'єктивності та об'єктивності залежить від наслідків для буття системи, тому у науковому сенсі доцільно говорити не про поняття, а про концепт "небезпека".

2. Соціальне явище, яке визначають концептом "безпека" існує лише у живій природі, а його сутність має розкриватися через сутність соціального явища, яке визначають концептом "небезпека" Природа небезпеки зумовлює можливу неадекватну оцінку безпеки суб'єкта, коли він починає діяти виходячи власних уявлень про небезпеку, що зумовлює необхідність розгляду концепту "безпека" як наукової категорії, яка відображає універсальні властивості та закономірності розвитку матеріальних, природних і духовних явищ, як елементів об'єктів реального світу, а трансорормації в різних сферах суспільного життя в епоху постмодерну спонукають до подальшого з'ясування онтологічного, гносеологічного та аксіологічного аспектів проблеми забезпечення безпеки.

3. Зміст, який характеризує об'єктивні властивості, складові та ознаки і форма, як сукупність зв'язків структури змісту соціальних явищ, які визначають концептом "безпека", пов'язується з наявністю умов буття соціальних систем, тому вони $€$ фундаментальною та системною характеристикою їх розвитку, який акумулює наслідки багатогранної діяльності цих систем. Причини й динаміка розвитку цього соціального явища, тобто його якісно-кількісний стан, можуть бути розкриті категоріями буття: "якість" (дає змогу дійти висновку про сталість явища й характеризує внутрішню нероздільну визначеність та сукупність його суттєвих рис); "кількість" (відображає мінливість явища та є зовнішньою характеристикою ступеня розвитку його властивостей: динаміки змін, кількісних наслідків, тощо; структура (відображає єдність, взаємозв'язок, залежність якості та кількості, що перебувають в нерозривній єдності згідно з законом переходу кількісних змін в якісні).

4. Управлінські рішення щодо забезпечення безпеки соціальних систем необхідно приймати на основі результатів аналізу динаміки їх розвитку, результатів фрілософсько-політологічного, правового, ціннісного та етичного аспектів проблеми ії̈ забезпечення та законів еволюції живої речовини в біосфері.

Перспективи подальших досліджень полягають у розробці концептуальних засад формування механізмів реагування на небезпеки соціальним системам.

Література:

1. Аристотель. Политика. Соч. в 4 т. - М.: Политиздат, 1983. - Т. 4. - С. - 509. 
2. Томас Гоббс. Левиафран. М.: Рипол Классик. 2016. -608 c.

3. Локк Дж. Сочинения:В3 т. Т. 3.- М.: Мысль, 1988. С. $137-405$.

4. Гегель Г. Основи фрілософрії права, або природне право і державознавство: пер. 3 нім. / Г. Гегель; Пер. Р. Осадчук, М. Кушнір. - К.: Юніверс, 2000. - 329 с.

5. Руссо Жан-Жак Про суспільну угоду, або принципи політичного права: пер. з фр. та коментарі: О. Хома. K.: Port-Royal, 2001. - 349 c.

6. Дюркгейм Э. О разделении общественного труда. Метод социологии. Пер. с фр. и послесл. Л.Б.Гофмана. - М.: Наука, 1991. - 576 с.

7. Бодрийяр Ж. Символический обмен и смерть / Ж. Бодрийяр. - М.: Добросвет, 2000. - 387 с.

8. Бауман 3. Текучая современность / Пер. с англ. под ред. Ю.В. Асочакова. - СПб.: Питер, 2008. - 240 с.

9. Foucault Michel Surveiller et punir: Naissance de la prison. - Paris: Gallimard, 1975. - 328 c.

10. Могилевский В.Д. Введение в теорию управления безопасностью систем / / Проблемы безопасности при чрезвычайных ситуациях. - 2001. - № 4. С. $215-236$.

11. Симчич М.В. Категорія. Енциклопедія сучасної України: у 30 т. / Ред. кол. І.М. Дзюба [та ін.]; НАН України, НТН, Координаційне бюро енциклопедії сучасної України НАН України. - К., 2012. - Т. 12. - 711 с.

12. Сен-Симон, А. Избранные сочинения. Том 1: пер. с фрр. под ред. и с коммент. Л.С. Цеплина. - МоскваЛенинград: Изд-во Академии наук СРСР, 1948. - 470 с.

13. Тлумачний словник - мінімум української мови / Укл. Л.О. Ващенко, О.М. Єфрімов. - 2-е вид. - К.: Довіра, 2000. - 546 с.

14. Орел М.Г. Теоретичні основи державного управління у сорері політичної безпеки: монографрія / М.Г. Орел. - К.: "Поліграфр плюс", 2019. - 320 с.

References:

1. Aristotel'. (1983), Politika [Politics], Politizdat, Moscow, Russia.

2. Gobbs, T. (2016), Leviafan [Leviathan], Ripol Klassik, Moscow, Russia.

3. Lokk, Dzh. (1988), Sochinenija [Works], Mysl', Moscow, Russia.

4. Hegel, G. (2000), Osnovy filosofii prava, abo pryrodne pravo i derzhavoznavstvo, [Fundamentals of the philosophy of law, or natural law and state studies], Yunivers, Kyiv, Ukraine.

5. Russo, Zhan-Zhak (2001), Pro suspil'nu uhodu, abo pryntsypy politychnoho prava [About the social agreement or the principles of political law], Port-Royal, Kyiv, Ukraine.

6. Djurkgejm, Je. (1995), Sociologija. Ee predmet, metod, prednaznachenie [Tsotsiology. Its subject, method and mission], Kanon, Moscow, Russia.

7. Bodrijjar, Zh. (2000), Simvolicheskij obmen i smert' [Symbolic exchange and death], Dobrosvet, Moscow, Russia.

8. Bauman, Z. (2008), Tekuchaja sovremennost' [Flowing modernity], Peter, St. Petersburg, Russia.

9. Foucault, M. (1975), Surveiller et punir: Naissance de la prison, Gallimard, Paris, France.

10. Mogilevskij, V.D. (2002), "Dynamic systems: technologies of transformation and destruction", Problemy bezopasnosti pri chrezvychajnyh situacijah, vol. 1, pp. 86 $-99$.

11. Cymchych, M.V. (2012), Katehoriia. Entsyklopediia suchasnoi Ukrainy [Category. Encyclopedia of modern Ukraine], vol.12, NAN Ukrainy, NTN, Koordynatsijne biuro entsyklopedii suchasnoi Ukrainy NAN Ukrainy, Kyiv, Ukraine.

12. Sen-Simon, A. (1948), Izbrannye sochinenija [Selected Works], vol. 1, Akademii nauk SRSR, Moscow - St. Petersburg, Russia.

13. Vaschenko, L.O. and Yefimov, O.M. (2000), Tlumachnyj slovnyk - minimum ukrains'koi movy [Interpretive dictionary - a minimum of Ukrainian], Dovira, Kyiv, Ukraine.

14. Orel, M.G. (2019), Teoretychni osnovy derzhavnoho upravlinnia u sferi politychnoi bezpeky [Theoretical Foundations of Public Administration in Political Security], Polihraf plius, Kyiv, Ukraine. Стаття надійшла до редакиї 19.08.2019 p.

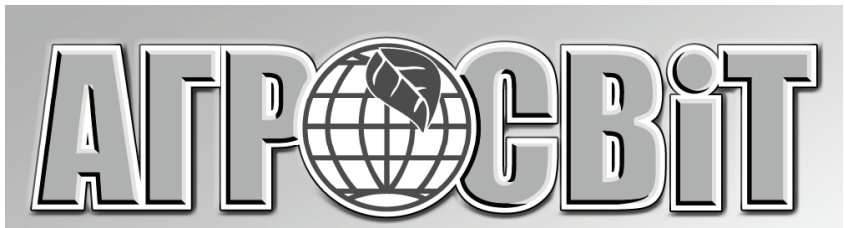

www. agrosvit. info

Передплатний індекс: 23847

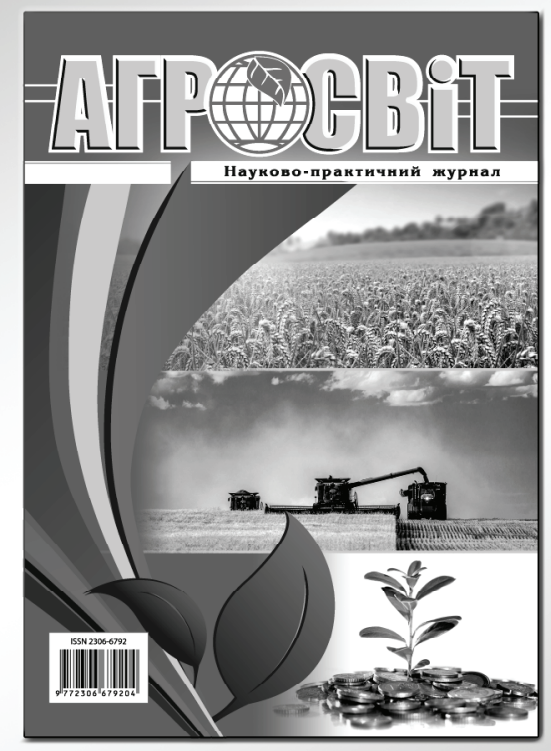

Виходить 24 рази на рік

Видання включено до переліку наукових фахових видань України 3 ЕКОНОМІКИ 